\title{
Intradural extramedullary spinal hydatidosis: case report
}

\author{
A. Kaen; A. Lagares; A. Perez-Nuñez; J.J. Rivas; A. Ramos* and R.D. Lobato
}

Department of Neurosurgery and Neuroradiology*. Hospital 12 de Octubre. Madrid. Spain.

\section{Summary}

The parasitic tapeworm Echinococcus granulosis causes hydatid disease, which is rarely encountered in nonendemic regions. It is a progressive disease with serious morbidity risks. Rarely, these cysts are found in the spine. They are mainly found epidurally, originating from direct extension from pulmonary, abdominal or pelvic infestation. Nevertheless, the main mechanism for intradural involvement is not yet clear. Antihelminthic treatment should be administered for a long period following early decompressive surgery. We report a case of recurrent hydatid disease that presented unusual intradural dissemination. Prognosis for spinal hydatid disease remains very poor and comparable to that of a malignant neoplasm.

KEY WORDS: Hydatid cysts. Intradural. Spine. Echinococcus.

Hidatidosis espinal intradural extramedular: presentación de un caso

\section{Resumen}

El Equinococcus granulosis es el parásito causante de la hidatidosis, que se encuentra de forma muy poco frecuente en regiones no endémicas. Es una enfermedad quística progresiva con riesgo de causar morbilidad importante, afectando principalmente al hígado y al pulmón. Muy raramente se encuentran quistes a nivel espinal. La hidatidosis espinal afecta sobre todo al espacio epidural por extensión directa de infección existente a nivel pulmonar, abdominal o pélvico. No obstante, el mecanismo para la afectación intradural todavía no está aclarado. El tratamiento antihelmíntico ha de ser administrado durante largo tiempo tras la cirugía descompresiva. Presentamos el caso de una hidatidosis espinal recurrente que presentó una diseminación

Recibido: 12-03-08. Aceptado: 1-09-08 intradural inusual. El pronóstico de la hidatidosis espinal continúa siendo muy pobre, comparable al de una enfermedad neoplásica maligna.

PALABRAS CLAVE: Hidatidosis. Intradural. Espinal. Echinococcus.

Introduction

Hydatid disease is caused by the larval form of Echinococcus granulosis and the most common form of presentation is by lung and liver cysts. Spinal hidatidosis is extremely $^{6}$ rare and cysts are most frequently located at the epidural level, originating from direct extension from pulmonary, abdominal or pelvic infestation ${ }^{2}$. Although the standard treatment is total surgical removal of the cysts without inducing any spillage, it not may be possible to perform this in patients with multiple and fragile cysts. In such cases, the neural structures should be satisfactorily decompressed and albendazole should be administered promptly. However, the success in the treatment of vertebral hydatidosis represents a challenge due to its invasive nature; consequently its poor prognosis has been compared with that of malignant spinal tumor. We report the case of a patient with recurrent hydatid disease who had an unusual intradural dissemination without cerebral involvement.

\section{Case Report}

This 59-year-old man consulted because of back pain and progressive difficulty in walking. He had been both pharmacologically (the patient received mebendazole $40 \mathrm{mg} / \mathrm{kg}$ ) and surgically treated for more than twenty years for recurrent hydatid disease affecting the lungs and liver. One year before admission he had been implanted a lumbar catheter for infusion of opioids, but it was removed because of poor analgesic response. His pain had progressively increased for 4 months. Physical examination showed local tenderness at the middle and lower thoracic regions, bilateral lower extremity weakness (4/5), bilateral Babinski sign, and hypoesthesia below T6. Bowel and 

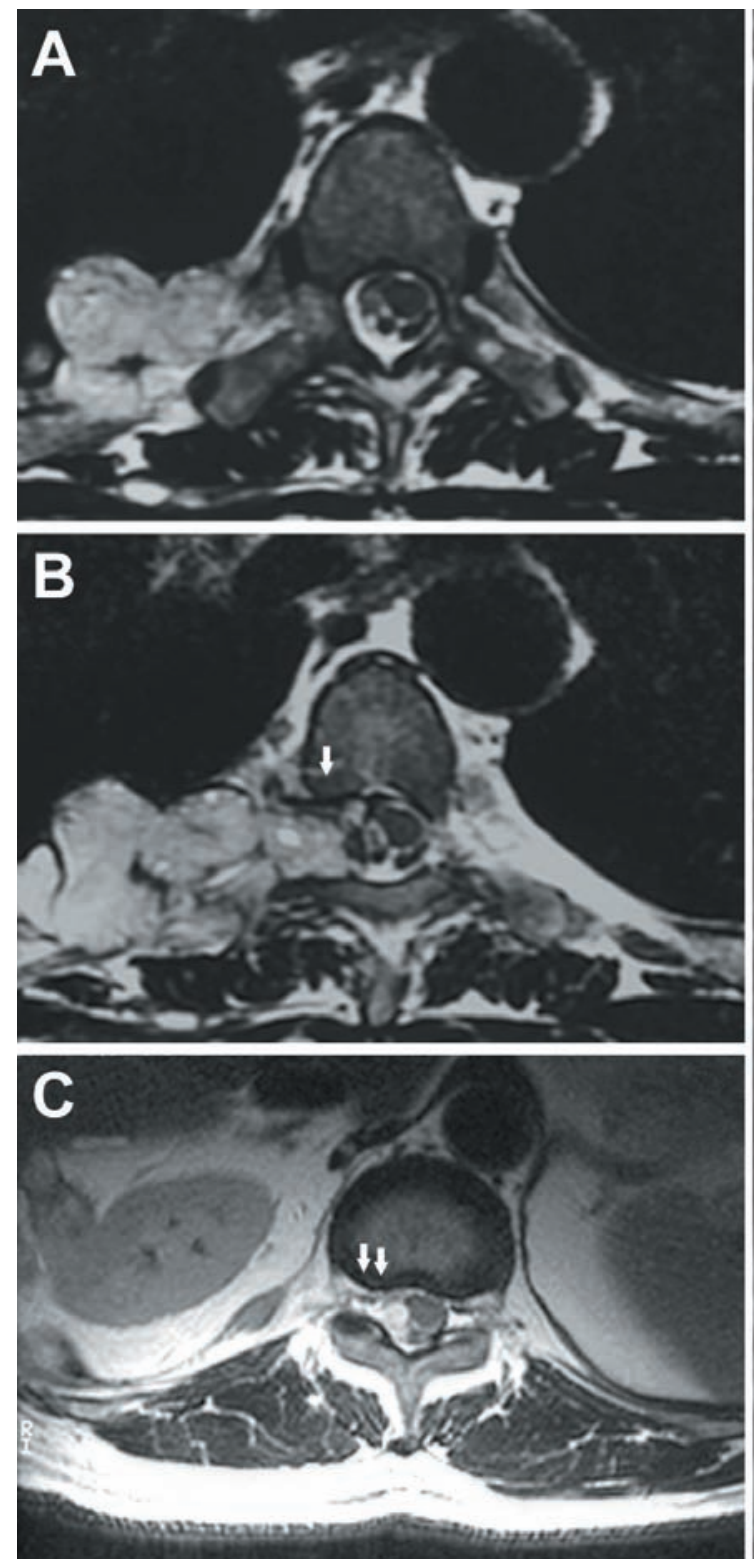

bladder functions were intact. A MR of the thoracic and lumbar spine revealed several multiloculated non calcified cysts in the spinal canal which were clustered at two levels; some located at T6 in connection with intrathoracic hydatid infestation which protruded into the canal through the destroyed right T6 pedicle an apparently extradural; others at T10 and T12 level seemed extradural too (fig. 1). Routine laboratory results were normal with the exception of a high erythrocyte sedimentation rate. With the diagnosis of epidural spinal hidatydosis he was operated on performing a T5-T6 and T9-T12 laminectomy. Although cystic lesions that had been found at T6 were extradural and connected to those present in the chest, no epidural lesions were found at T9-T12 level. To prevent the disease spreading intraduraly the operation was terminated and a control MR confirmed

2009 20: 282-287

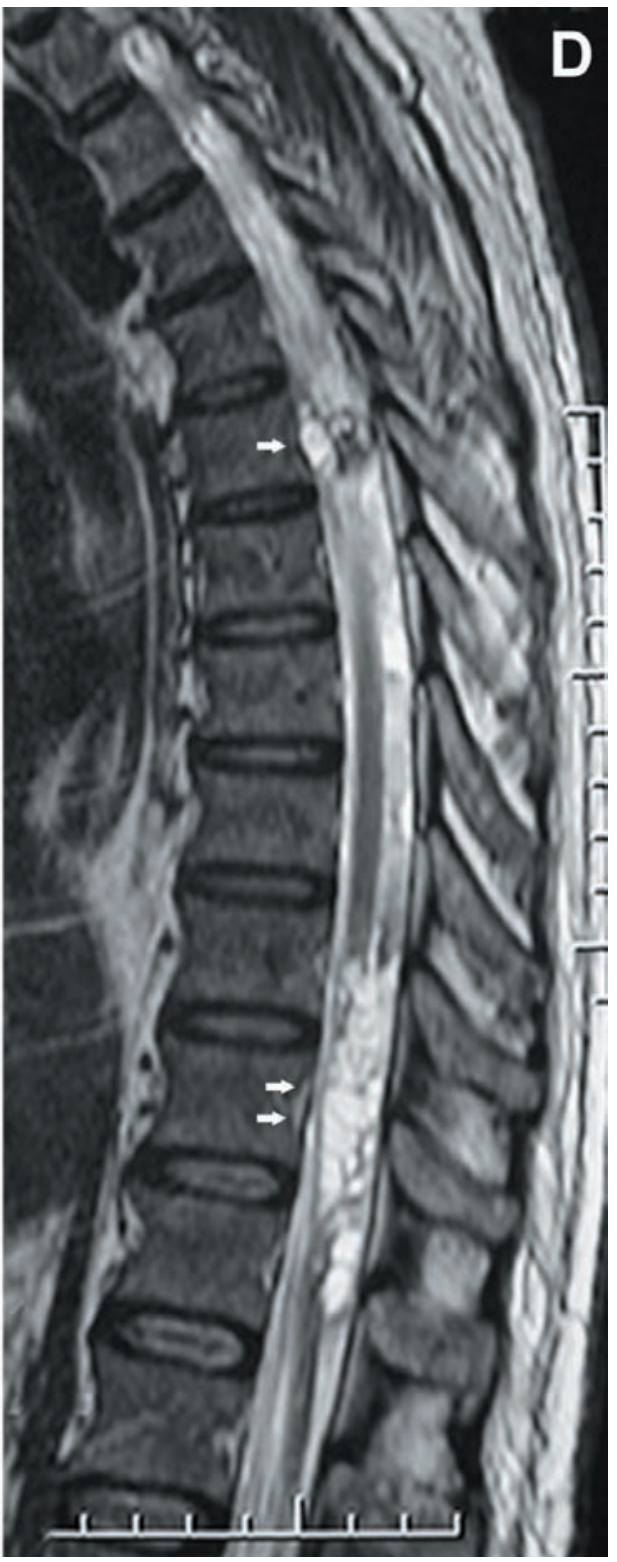

the intradural presence of hydatid cysts. The surgical field was irrigated with hypertonic saline $(20 \%)$ and povidone iodine. Histopathological examinations confirmed hydatid disease.

The patient was operated on again after a couple of days and after durotomy multiple extramedullary cysts were found, covered by a thick arachnoid reaction which made the extraction of cysts very difficult. During surgery the field was irrigated with hypertonic saline solution. The patient recovered from surgery without new deficits and was able to walk without assistance at discharge. Albendazole $(15 \mathrm{mg} / \mathrm{kg}$ for 6 months $)$ was given in the postoperative period. Six mouths later, he experienced back pain irradiated through L4-L5 territory bilaterally. Lumbar MR study showed multiple cysts compressing and displacing 

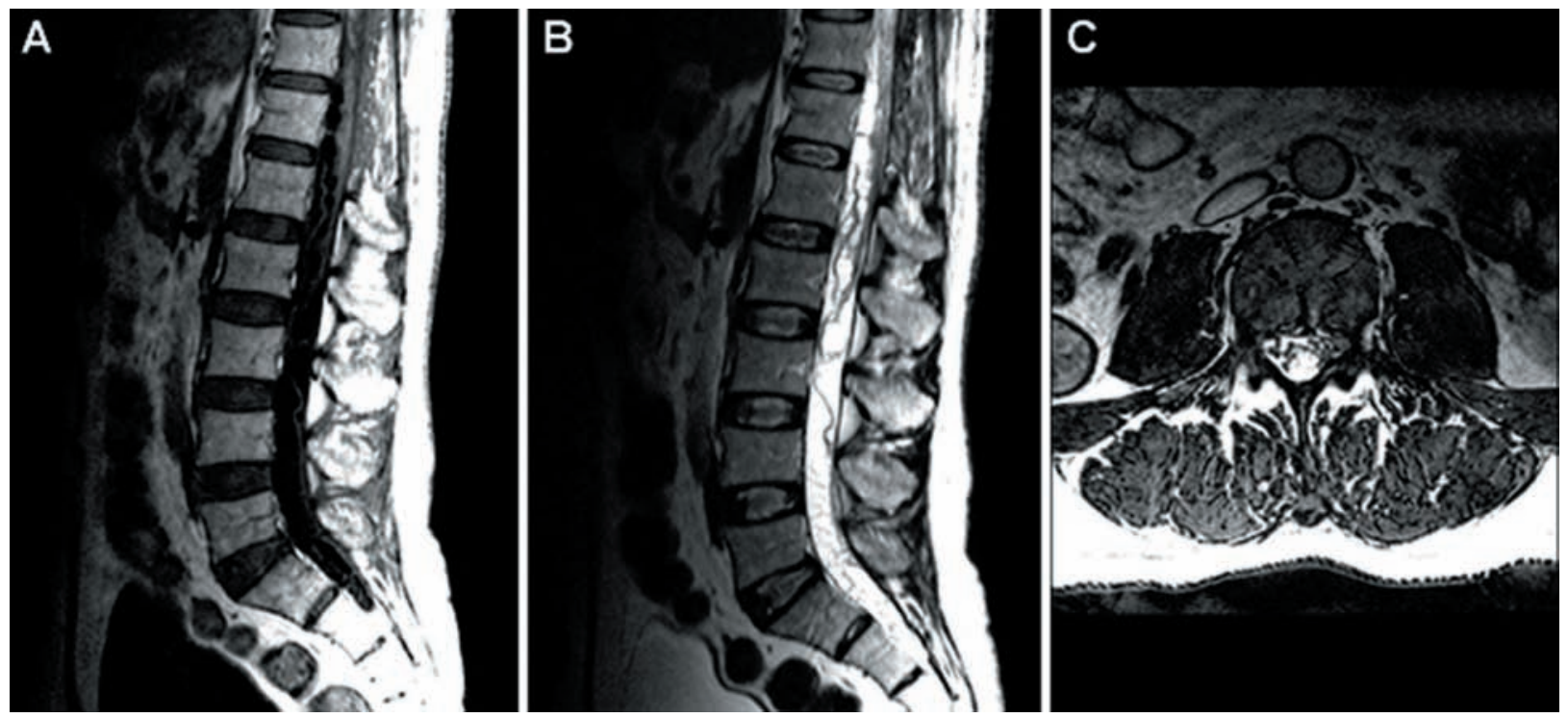

Figure 2. Lumbar sagital T1(A), T2 (B) and axial T2 (C) weighted MR images showing multiple round lesions of varying size, with an intensity similar to that of the cerebrospinal fluid, revealing lumbar intradural extramedullary involvement.
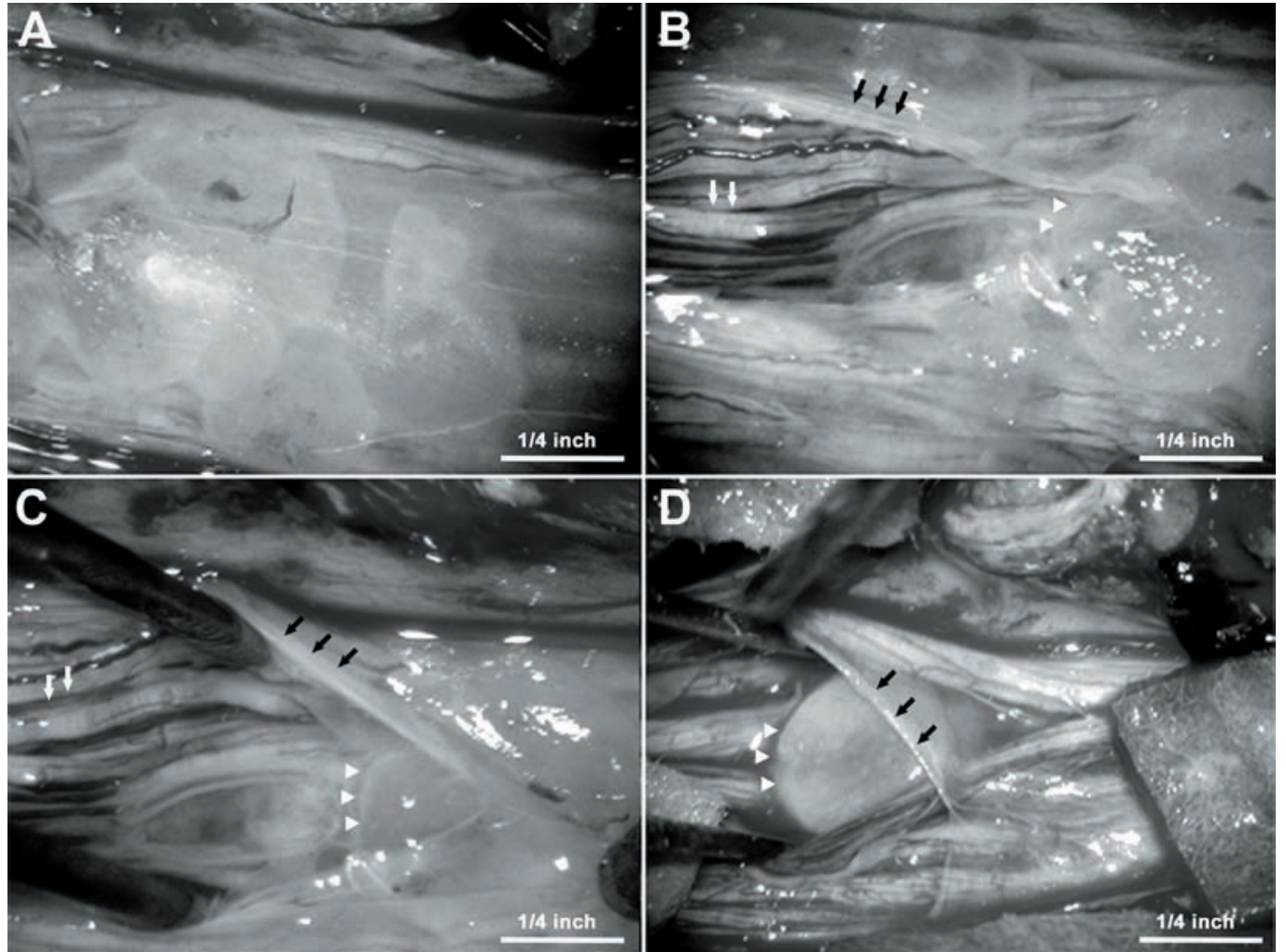

Figure 3. Intraoperative photograph showing multiple intradural cysts (A) covered by a thick arachnoid reaction, displacing and distorting the roots of the cauda equine. Thereafter, a durotomy was performed ( $B$ and $C$ ), and hydatid cysts were carefully removed between lumbo-sacral nerves (E).

the cone and lumbar roots from T12 to the sacral area (fig. 2). Cervical and cranial MR did not reveal any lesion, and thoracic spine MR showed postoperative changes without the presence of new lesions. A T12-S1 laminectomy was performed and multiple cysts were found intradurally, covered by a thick arachnoid reaction, displacing and distorting the roots of the cauda equine (fig. 3). Most cysts were aspirated since careful dissection and individual extraction were impossible without injuring the roots. After the surgery the patient developed urinary and fecal incon- 

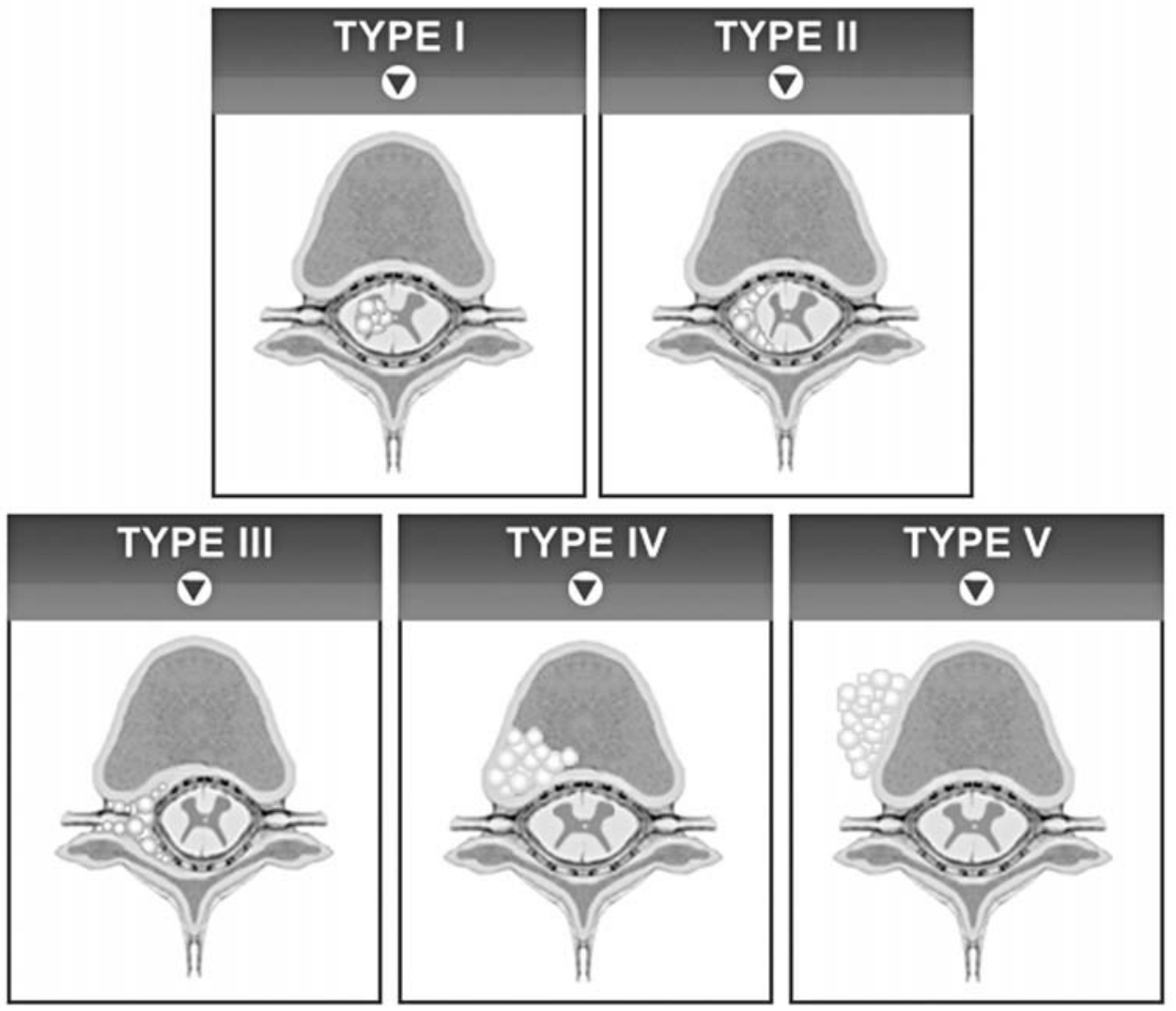

Figure 4. Braithwaite and Lees classification.

tinence associated to an increase in his lower extremity weakness. He was transferred to a rehabilitation unit where the patient's neurologic status improved, and he was able to walk without support three months after the operation.

The patient had to be readmitted three months later because he reported that he had suffered several falls in the last week. He also complained of pain in the lower extremities without a clear radicular pattern, increasing instability $3 / 5$ motor strength in both legs. A spinal MR showed recurrent intradural hydatid disease in the thoracic and lumbar spine with the development of new intradural lesions from C6 to T4, which posteriorly compressed the spinal cord. These new cervical lesions were operated on through a C5T4 laminectomy, but despite the evacuation of these cysts, the patient's neurological condition gradually worsened and three weeks after the operation he remained paraplegic with a T10 sensory level and new multiple intradural cysts below the level of the last surgery.

\section{Discussion}

Hydatidosis is caused by two larval forms of Echinococcus, E. granulosus and less commonly E. multilocularis. The most common site of infection is the liver $(74 \%$ of the cases) and lungs ( $15 \%$ of the cases $)^{2}$. This disease is extremely uncommon in developed countries, like North America and Europe, and more frequent in countries with poor socio-sanitary conditions ${ }^{19}$.

Infection of the central nervous system is unusual, and only between 2 and $4 \%$ of the patients with hydatid disease present brain cysts ${ }^{10,18}$. Bone involvement occurs in $1 \%$ of the patients, and approximately half of them show spinal involvement. Any segment of the spine can be affected, including the thoracic (50\%), lumbar (20\%), sacral $(20 \%)$ and cervical $(10 \%)$ regions ${ }^{7,8}$. These segments can be affected by an isolated or by multiple cysts. Infestation may occur at any location, primarily or by metastatic seeding of protoscolices released from another location.

The clinical presentation of spinal hydatidosis is variable, including paraparesis $(62 \%)$ or paraplegia $(26 \%)$, back pain or radicular pain $(55 \%)$, numbness or sensitivity loss $(36 \%)$ and sphincter disturbance $(30 \%)^{2}$. Morphologically, spinal involvement has been classified by Braithwaite and Lees $^{5}$ (Figure 4) into five types: 1) Primary intramedullary hydatid cysts; 2) Intradural extramedullary hydatid cysts; 3) Extradural intraspinal hydatid cysts; 4) Vertebral hydatidosis; and 5) Paravertebral hydatidosis. The intradural and extramedullary involment, like our case, is extremely $\operatorname{rare}^{1,4,9,10,13,14,16}$, especially in non-endemic countries.

Diagnosis has been improved with the use of MR. 
Hydatid cysts have an unique appearance on MR. On T1weighted images viable cysts appear to contain a low intensity fluid surrounded by an iso- to mildly hyperintense wall which on T2-weighted images appears as a low-intensity rim surrounding the high signal cyst content. The appearance of the cysts on T2-weighted images indicate their viability, as a decrease in the intensity of the signal of the content and an increase of the signal of the cyst walls indicate a dying cyst ${ }^{17}$.

One of the main points regarding our case is the occurrence of intradural extramedullary spinal hydatidosis without macroscopic involvement of the brain. In our case the initial spinal hidatidosis spread to the intradural space, so he deteriorated from type III to type II of Braithwaite and Lees classification ${ }^{5}$.The route of spread of the disease to the spine is still not fully determined. Spinal hydatidosis usually begins in the marrow of a vertebral body and may progress around the neural arch, through adjacent ribs, reaching the spinal canal or the intervertebral discs; thus spinal involvement is believed to occur through vertebralportal venous anastomosis ${ }^{19}$. In addition, extradural disease may spread through the neural foramen into the surrounding soft tissues as in the initial upper thoracic involvement in our case. However, the main mechanism for the intradural extramedullary involvement is not yet clear. Primary hematic dissemination is regarded as the most plausible mechanism ${ }^{2}$, but dural tearing during surgery or during an aggressive invasion of spinal space, like lumbar puncture, may have a role in the etiology of the spreading of the infestation into the intradural space. This mechanism is well known for bacterial dissemination, but not for parasite spread ${ }^{12}$. Although in our case there was such an antecedent, the dural puncture was located far away from the initial side of infestation. Moreover, during the first surgery we were not able to detect any dural defect. Therefore, the most plausible mechanism of the intradural spread of the disease in our case is hematic dissemination.

Operative procedures are the treatment for spinal cord compression caused by hydatid cysts. Laminectomy with simple decompression is the most frequent procedure. Unfortunately, the results of surgical treatment are not gratifying, as apparent radical removal is usually followed by recurrence or progression of the illness, as occurred in our patient. Intradural disease is also associated with intense arachnoiditis, which difficults surgical resection of the cysts and increases the risk of neurological deterioration as well as of spreading of the disease through the subarachnoid space, a fact that might have occurred in our patient ${ }^{11,15}$. To prevent recurrence or spreading of the disease, irrigation with hypertonic saline or a diluted Betadine solution after removal of the cysts has been proposed; other authors have used $10 \%$ formalin solution to irrigate the surgical field, but the dura should not be opened ${ }^{18-21}$. Anyway the efficacy of these methods remains unproven.

Pharmacological treatment of hydatid disease, especially when combined with surgical treatment, has reached some degree of success ${ }^{13}$. Albendazole and mebendazole are the main anti-helmintic drugs used. Nevertheless, bony involvement has demonstrated a less favorable response than other sites ${ }^{3}$.

Despite the increasing use of surgical and medical treatment, prognosis for spinal hydatid disease remains very poor and it is comparable to that of a malignant neoplasm.

\section{References}

1. Akhan, O., Dincer, A., Saatci, I., et al.: Spinal intradural hydatid cyst in a child. Br. J. Radiol 1991; 64: 465-466.

2. Altinors, N., Bavbek, M., Caner, H.H., et al.: Central nervous system hydatidosis in Turkey: a cooperative study and literature survey analysis of 458 cases. J. Neurosurg 2000; 93: 1-8.

3. Baykaner, M.K., Dogulu, F., Ozturk, G., et al.: A viable residual spinal hydatid cyst cured with albendazole. Case report. J. Neurosurg 2000; 93: 142-144.

4. Berk, C., Ciftci, E., Erdogan, A.: MRI in primary intraspinal extradural hydatid disease: case report. Neuroradiology 1998; 40: 390-392.

5. Braithwaite, P.A., Lees, R.F.: Vertebral hydatid disease: radiological assessment. Radiology 1981; 140: 763-766.

6. Charles, R.W., Govender, S., Naidoo, K.S.: Echinococcal infection of the spine with neural involvement. Spine 1988; 13: 47-49.

7. Garcia-Vicuna, R., Carvajal, I., Ortiz-Garcia, A., et al.: Primary solitary Echinococcosis in cervical spine. Postsurgical successful outcome after long-term albendazole treatment. Spine 2000; 25: 520-523.

8. Islekel, S., Ersahin, Y., Zileli, M., et al.: Spinal hydatid disease. Spinal Cord. 1998; 36: 166-170.

9. Islekel, S., Zileli, M., Ersahin, Y.: Intradural spinal hydatid cysts. Eur. Spine J 1998; 7: 162-164.

10. Jiménez, J., Ugarriza, F., Porras, L., Yagüe, L., Gómez, L., Cabezudo, J.M.: Hidatidosis espinal: revisión de 6 casos. Neurocirugía 2001; 12: 214.

11. Karray, S., Zlitni, M., Fowles, J.V., et al.: Vertebral hydatidosis and paraplegia. J. Bone Joint Surg Br 1990; 72: 84-88.

12. Killough, K.R., Lushbaugh, W.B, Harkey, H.L.: Parasitic Infections of the Spine, in Osenbach R.K., Zeidman S.M. (eds): Infections in Neurological Surgery. Philadelphia: Lippincott-Raven, 1999; pp 305-309.

13. Lam, K.S., Faraj, A., Mulholland, R.C., et al.: Medical decompression of vertebral hydatidosis. Spine 1997; 22: 20502055.

14. Onbas, O., Kantarci, M., Alper, F., et al.: Spinal widespread intradural extramedullary hydatidosis. Neuroradiology 
2004; 46: 310-312.

15. Pamir, M.N., Ozduman, K., Elmaci, I.: Spinal hydatid disease. Spinal Cord. 2002; 40: 153-160.

16. Pau, A., Simonetti, G., Tortori-Donati, P., et al.: Computed tomography and magnetic resonance imaging in spinal hydatidosis. Surg Neurol 1987; 27: 365-369.

17. Pesudo, J.V., Laguía, M., Roldán, P., Pallardó, Y., Cerdá, M., García-March, Blasco, C., Barcia, J.L.: Equinococosis vertebral: a propósito de un caso. Neurocirugía 1998; 19: 251-256.

18. Sami, A., Elazhari, A., Ouboukhlik, A., et al.: [Hydatid cyst of the spine and spinal cord. Study of 24 cases]. Neurochirurgie 1996; 42: 281-287.

19. Schnepper, G.D., Johnson, W.D.: Recurrent spinal hydatidosis in North America. Case report and review of the

\section{Comentario al trabajo Intradural extramedullar spinal hydatidosis: case report de Ariel Kaen y cols.}

Los autores Ariel Kaen y cols., presentan un caso de hidatidosis espinal con diseminación intraespinal tras la cirugía, con un pronóstico funcional fatal. Parasitosis como la hidatidosis o la neurocistiercosis suponen en la actualidad un grave problema de salud pública en países subdesarrollados donde esta enfermedad es endémica. Las fuertes corrientes migratorias así como el acceso constante de viajeros de nuestros países a dichas zonas han sido responsables de la reaparición de la citada patología en nuestros hospitales. La hidatidosis suele afectar a la columna vertebral en menos de un $1 \%$ de los casos. El tratamiento quirúrgico realizado por los autores suele ser el indicado en la literatura; aunque el tratamiento de elección es la exéresis total de los quistes, muchas veces el neurocirujano tiene que conformarse con realizar una descompresión del canal espinal. Es fundamental no romper los quistes durante la cirugía para evitar la diseminación de la enfermedad,
2009 20: 282-287

literature. Neurosurg. Focus 2004; 17: E8.

20. Spektor, S., Gomori, J.M., Beni-Adani, L., et al.: Spinal echinococcal cyst: treatment using computerized tomographyguided needle aspiration and hypertonic saline irrigation. Case report. J. Neurosurg 1997; 87: 464-467.

21. Turtas, S., Viale, E.S., Pau, A.: Long-term results of surgery for hydatid disease of the spine. Surg Neurol 1980; 13 : 468-470.

Kaen, A.; Lagares, A.; Perez-Nuñez, A.; Rivas, J.J.; Ramos, A.; Lobato, R.D.: Intradural extramedullary spinal hydatidosis: case report. Neurocirugía 2009; 20: 282-287.

Correspondence: Ariel Kaen. Servicio de Neurocirugía. Hospital 12 de Octubre. Avda. Córdoba s/n. 28041. Madrid. Spain.

en este aspecto, maniobras como la irrigación con suero salino hipertónico son de dudosa eficacia. Es mandatario el tratamiento con albenzadol durante un periodo mínimo de 3-4 meses. Los autores recogen una afirmación de la literatura donde comparan el pronóstico final de la enfermedad con una neoplasia maligna. En nuestra experiencia, encontramos algún caso de hidatidosis pulmonar con invasión espinal en los que hemos conseguido mediante descompresión y tratamiento el control de la enfermedad durante varios años. En este tipo de casos donde el riesgo de rotura de las vesículas es alto (cercano al 44\%) y la recurrencia de la enfermedad es del 30 al 100\%, a veces sería preferible adoptar posturas menos agresivas y realizar descompresión y tratamiento médico.

J. Enseñat Nora Barcelona 